\title{
Lossless Compression of Video using Motion Compensation
}

\author{
Martins, Bo; Forchhammer, Søren
}

Published in:

Data Compression Conference, 1998. DCC '98. Proceedings

Link to article, DOI:

10.1109/DCC.1998.672302

Publication date:

1998

Document Version

Publisher's PDF, also known as Version of record

Link back to DTU Orbit

Citation (APA):

Martins, B., \& Forchhammer, S. (1998). Lossless Compression of Video using Motion Compensation. In Data Compression Conference, 1998. DCC '98. Proceedings (pp. 560-560). IEEE.

https://doi.org/10.1109/DCC.1998.672302

\section{General rights}

Copyright and moral rights for the publications made accessible in the public portal are retained by the authors and/or other copyright owners and it is a condition of accessing publications that users recognise and abide by the legal requirements associated with these rights.

- Users may download and print one copy of any publication from the public portal for the purpose of private study or research.

- You may not further distribute the material or use it for any profit-making activity or commercial gain

- You may freely distribute the URL identifying the publication in the public portal

If you believe that this document breaches copyright please contact us providing details, and we will remove access to the work immediately and investigate your claim 


\section{Lossless Compression of Video using Motion Compensation}

\section{Bo Martins and Søren Forchhammer}

Dept. of Telecommunication ${ }^{1}, 371$, Technical University of Denmark e-mail: bm@tele.dtu.dk and sf@tele.dtu.dk

We investigate lossless coding of video using predictive coding and motion compensation. The new coding methods combine state-of-the-art lossless techniques as in [1] (context based prediction and bias cancellation, Golomb coding) with high resolution motion field estimation, 3d-dimensional predictors, prediction using one or multiple $(\mathrm{k})$ previous images, predictor dependent error modelling, and selection of motion field by code length. We treat the problem of precision of the motion field as one of choosing among a number of predictors. This way, we can incorporate $3 \mathrm{~d}$-predictors and intra-frame predictors as well. As in [2], we use bi-linear interpolation in order to achieve sub-pixel precision of the motion field. Using more reference images is another way of achieving higher accuracy of the match. The motion information is coded with the same algorithm as is used for the data. For slow pan or slow zoom sequences, coding methods that use multiple previous images perform up to $20 \%$ better than motion compensation using a single previous image and up to $40 \%$ better than coding that does not utilize motion compensation.

Mobile and Calender

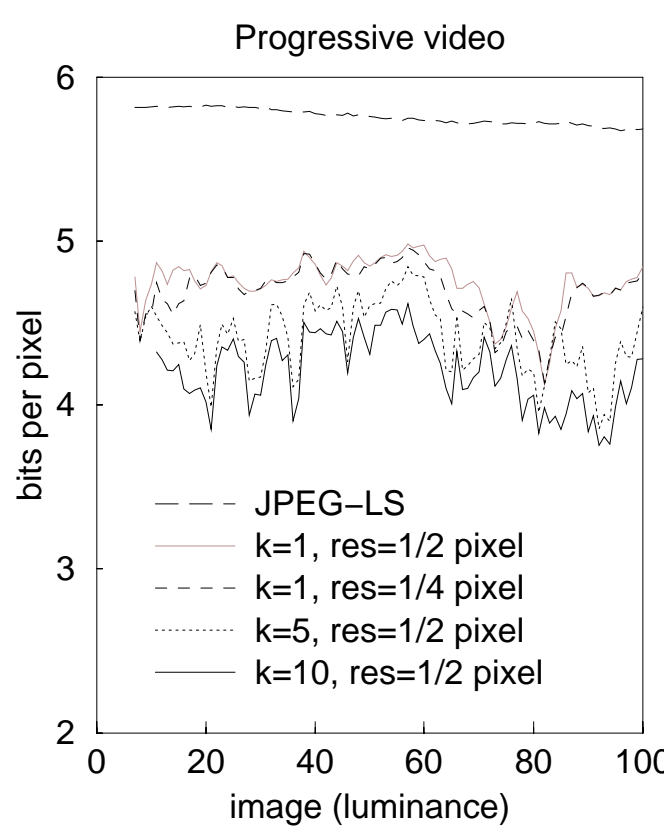

Barcelona

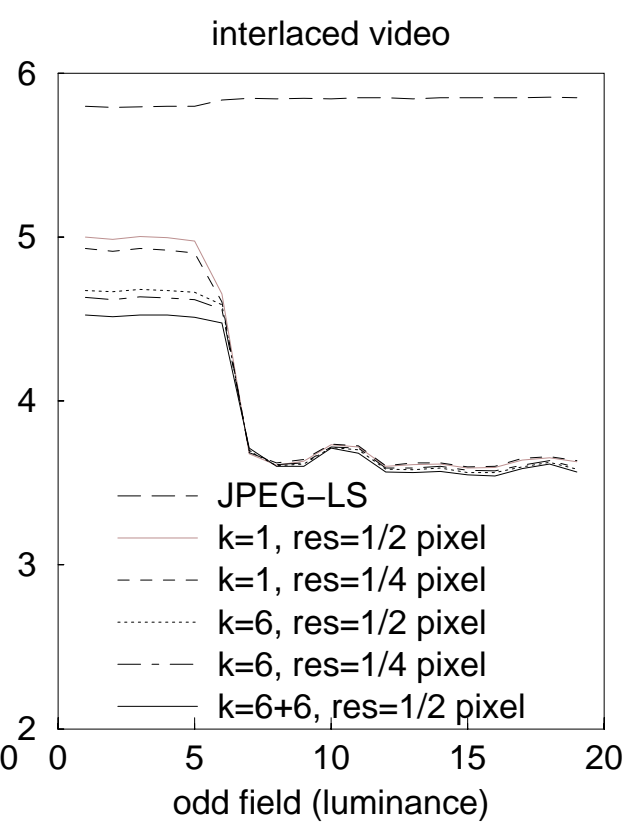

\section{References}

[1] JPEG-LS. CD 14495, Lossless and near-lossless coding of continuous tone still images (JPEG-LS). ISO/IEC Commitee Draft for an International Standard, 1997.

[2] J. Ribas-Corbera. Optimizing the motion vector accuracies in block-based video coding. PhD thesis, University of Michigan, 1996.

\footnotetext{
${ }^{1}$ The work was funded in part by The Danish National Centre for IT Research.
} 